\title{
NARRATIVE REPORTING OF INTELLECTUAL CAPITAL BY THE NEW ZEALAND LOCAL GOVERNMENT SECTOR
}

\author{
Annika Schneider \\ Herbert Mortan Accountants \\ abs_schneider@ihug.co.nz \\ Grant Samkin \\ University of Waikato, New Zealand \\ grantsam@waikato.ac.nz
}

June 2008

\begin{abstract}
This exploratory study investigates the extent to which 82 New Zealand local government authorities report intellectual capital in their annual reports. A disclosure index, constructed with the assistance of a 14-member local government stakeholder panel, was applied to the annual reports as part of a content analysis. Findings indicate that the overall level of intellectual capital disclosure was varied, with the majority of disclosures being narrative in nature. Findings also indicate that despite a significant portion of total annual expenditure being attributed to employees/staff, the level of human capital reporting was low.
\end{abstract}

Keywords:

Intellectual capital, disclosure, local government, New Zealand, intellectual capital approach, narrative reporting. 


\section{INTRODUCTION}

\subsection{Overview}

The study of intellectual capital as a discipline has experienced rapid growth during the last two decades. The intellectual capital movement emerged in the late 1980 s when a relatively small group of forward-thinking practitioners begun to seek alternatives to traditional accounting practice. They sought methods that adequately accounted for the value drivers of the 'new' economy. This new economy is the 'information age' and a key value driver is knowledge (Bontis, Dragonetti, Jacobsen \& Roos, 1999; Petty \& Guthrie, 2000). By accounting for intellectual capital, organisations seek to capture the value of knowledge and harness its value-creating potential.

\subsection{Defining intellectual capital}

While there is still disagreement over the definition of intellectual capital and its components in the literature (Lynn, 1998), most definitions recognise that intellectual capital represents knowledge transformed into something of value to an organisation (Collier, 2001; Guthrie \& Petty, 2000; Guthrie, Petty \& Johanson, 2001) and the recognition that intangibles can constitute claims to future benefits.

The disagreement over definitions has led to the development of a plethora of alternative intellectual capital disclosure, measurement and reporting models. While the models are different, each inherently recognises that organisational stakeholders require information extending beyond that delivered by traditional accounting practice (Organisation for Economic Cooperation and Development, 1999).

One of the models, the intellectual capital approach, represents a convergence of intellectual capital language and labels found in seminal work (Edvinsson \& Malone, 1997; Kaplan \& Norton, 1992; Rodgers, 2003; Roos, Roos, Dragonetti \& Edvinsson, 1997; Stewart, 1997; Sveiby, 1997). The intellectual capital approach is underpinned by the definition of intellectual capital succinctly encapsulated by the Organisation for Economic Cooperation and Development (OECD). The OECD describes intellectual capital as "the economic value of two categories of intangible assets of a company:

(a) organisational ('structural') capital and

(b) human capital".

Structural capital can be further disaggregated into internal and external capital. This definition recognises that intellectual capital is a distinct subset of, rather than the same as, the overall intangible asset base of an organisation.

By describing intellectual capital using three dimensions (human capital, internal capital and external capital, see TABLE 1 ), the dimensions are separated from each other, and boundaries for a framework are established (Mouritsen, Bukh \& Bang, 2005). The intellectual capital approach is supported by a number of authors in the intellectual capital literature (Brooking, 1996; Edvinsson \& Malone, 1997; Mouritsen, et al., 2005; Roos, et al., 1997; Sveiby, 1997) and has been highly influential in contributing to the popularisation of intellectual capital thematics. 
TABLE 1: The Intellectual Capital Approach

\begin{tabular}{|c|c|c|}
\hline $\begin{array}{l}\text { Intellectual } \\
\text { Capital } \\
\text { Dimension }\end{array}$ & $\begin{array}{c}\text { Alternative } \\
\text { label(s) }\end{array}$ & Description \\
\hline Internal capital & $\begin{array}{l}\text { Organisational } \\
\text { capital } \\
\text { Structural capital } \\
\text { Internal relations }\end{array}$ & $\begin{array}{l}\text { Refers to the knowledge embedded in organisational } \\
\text { structures and processes, and includes patents, research } \\
\text { and development, technology and systems. }\end{array}$ \\
\hline External Capital & $\begin{array}{l}\text { Customer capital } \\
\text { Relational capital } \\
\text { External relations }\end{array}$ & $\begin{array}{l}\text { Comprises elements of an organisation's patrimony- } \\
\text { related customer relations: relationships with customers } \\
\text { and suppliers, brand names, trademarks and } \\
\text { reputations. }\end{array}$ \\
\hline Human Capital & $\begin{array}{l}\text { Employee } \\
\text { competence }\end{array}$ & $\begin{array}{l}\text { Refers to the set of all the knowledge and routines } \\
\text { carried within the minds of the members of the } \\
\text { organisation and includes skills/competencies, training } \\
\text { and education, and experience and value characteristics } \\
\text { of an organisation's workforce/employees. }\end{array}$ \\
\hline
\end{tabular}

Source: Adapted from Fincham \& Roslender, 2003

\subsection{Measuring and reporting intellectual capital}

According to Fincham and Roslender (2003), the development of intellectual capital reporting models occurred in three distinct waves. The first wave of intellectual capital reporting consists of scorecard-type reporting mechanisms. These scorecards combined financial and nonfinancial information on certain intellectual capital 'indicators' in a narrative statement or report (Edvinsson \& Malone, 1997). Examples include the Skandia Navigator (Edvinsson \& Malone, 1997), the Balanced Scorecard (Kaplan \& Norton, 1992), and the Intangible Assets Monitor (Sveiby, 1997). These models are based on the Intellectual Capital Approach.

The second wave of intellectual capital reporting models attempted to link intellectual capital more explicitly with innovation and the value-creation process (Fincham \& Roslender, 2003). These models, developed in North America, attempted to determine where value was being created so it could be better managed. Models included in this wave were the Value Chain Scoreboard (Lev, 2001), the Value Creation Index (Kalafut \& Low, 2001; Low, 2000) and the Value Creation Pyramid (Canadian Performance Reporting Initiative, 1998; Fincham \& Roslender, 2003). Broadly speaking, these models suggest that the value of intellectual assets is the difference between the market value of a firm and its book value. However, there are a number of problems with this type of measure. The difference between market and book value cannot be wholly ascribed to intellectual assets (Bornermann, Knapp, Schneider \& Sixl, 1999; Brennan, 2001). Part of the difference may relate to unrealistic tangible asset values in firm balance sheets. In addition, share prices may fluctuate daily and may prove unreliable in measuring intellectual assets over the short term (Brennan, 2001). The value-based approaches only provide an overall measure of intellectual capital - separate elements are not measured.

The third wave of intellectual capital reporting saw the development of a more narrative-based format for intellectual capital reporting and includes Intellectual Capital Statements and Intellectual Capital Self-Accounts (Fincham \& Roslender, 2003). The Danish Agency for Trade 
and Industry (DATI) and the MERITUM project are the leaders in this wave of intellectual capital reporting (Petty \& Guthrie, 2000). Intellectual capital statements and intellectual capital reports provided organisations with the opportunity to express in narrative terms the intellectual capital of an organisation. These models saw a return to the narrative concepts explored in the first wave of intellectual capital reporting.

\subsection{Structure and contribution of the paper}

The next section of the paper examines the New Zealand local government sector in order to contextualise the paper. Prior literature concerned with intellectual capital disclosure in the annual reports of organisations is then considered. This is followed by the research questions and methodology and a presentation of the results of this study. Finally, the paper concludes by drawing attention to the limitations of the research.

This paper makes a contribution to the literature in three ways. Although it replicates the content analysis of a number of authors (Brennan, 2001; Guthrie \& Petty, 2000; Guthrie, Petty, Ferrier \& Wells, 1999; Wong \& Gardner, 2005), it differs in that this study applies to the local government sector whereas previous disclosure studies have focused on corporate intellectual capital disclosure. The study applies the methodology in a New Zealand setting. Finally, this study is more rigorous and representative as it focuses on a whole population of annual reports instead of a sample.

\subsection{The NZ Context}

New Zealand is a small country with a population of approximately 4.1 million. It is governed by a two-tier Westminster government system established in 1876, comprising central and local government. Central government (also known as Parliament) is elected to deal with issues relevant to New Zealand as a nation, whereas local government manages issues and services that affect local communities (The Department of Internal Affairs, 2006). There are 85 local authorities that constitute New Zealand's local government sector. The local government sector is structured into two principal forms: regional councils and territorial authorities (see FIGURE 1).

During the late 1980s and early 1990s the local government sector in New Zealand underwent significant reform (see Schneider \& Samkin (2008) for a detailed review of the reforms). The reforms were part of the broad central government financial management reforms of the time that aimed to increase the efficiency, effectiveness and accountability of all units of government. These reforms were facilitated by the legislative requirement in the Public Finance Act 1989 that required all government entities (both central and local government) to adopt the accrual accounting system and generally accepted accounting practice (GAAP) for financial reporting. The reforms changed the face of local government. The reforms drastically reduced the number of local authorities from over 600 local bodies to 86 smaller and more efficient authorities (Wallis \& Dollery, 2000). As of 6 March 2006, Banks Peninsula District Council amalgamated with Christchurch City Council, reducing the number of local authorities from 86 to 85. (For more detail see http://www.localcouncils.govt.nz.) Clear lines of responsibility were set out by the Public Finance Act 1989, as well as the requirements to adopt accrual accounting and commercial principles. These changes had the primary goal of increasing the accountability and transparency of the local governments to their communities. 


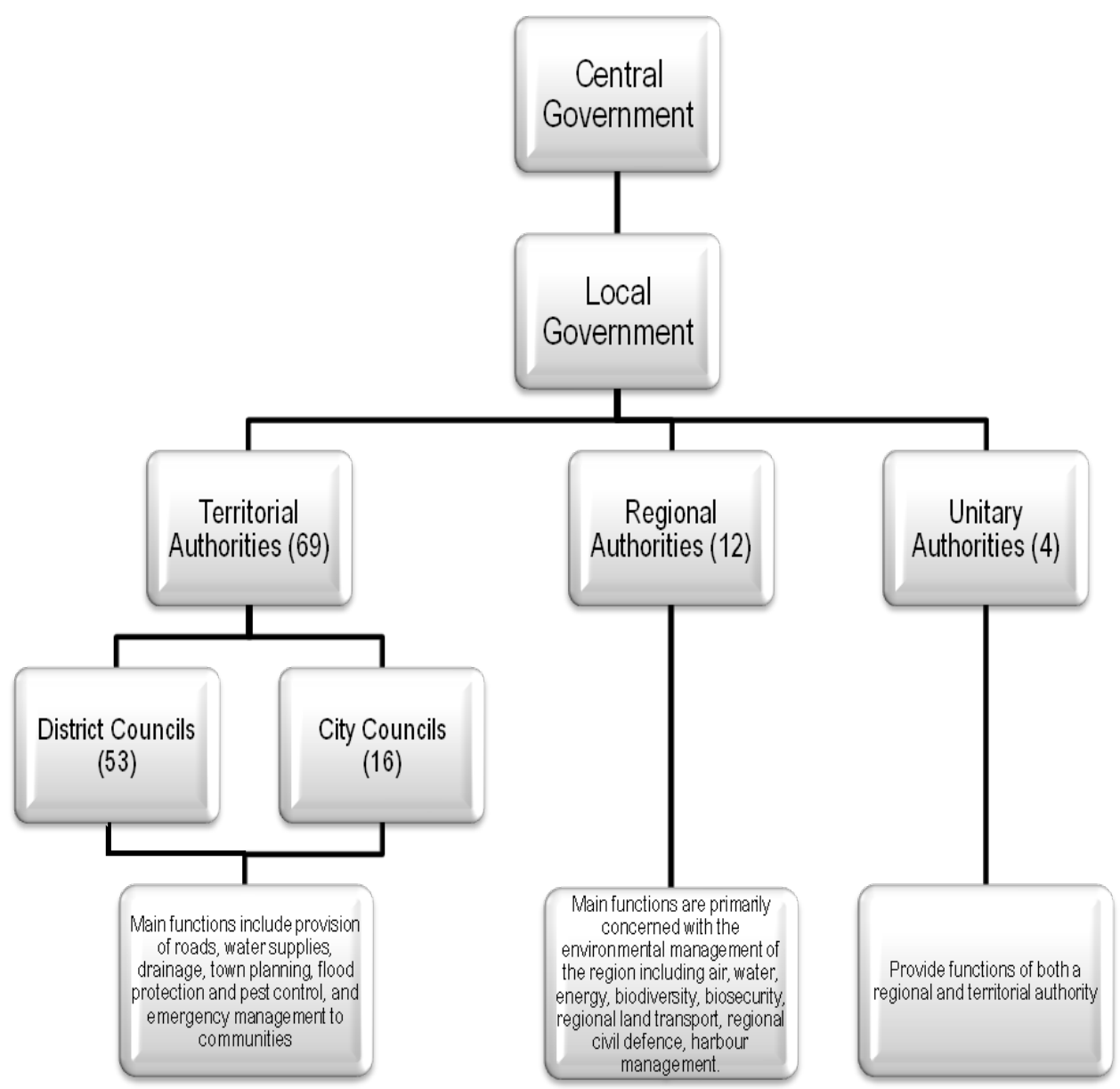

FIGURE 1: Structure of the New Zealand Local Government Sector

\section{Source: Author}

The New Zealand Local government sector makes a significant contribution to New Zealand's economy. The local government sector owns assets with a combined value of $\$ 79.4$ billion including $\$ 69.4$ billion in infrastructural assets (Localcouncils.govt.nz, 2007; The Department of Internal Affairs, 2007). This includes owning approximately $88 \%$ of New Zealand's road network. In the 2006 financial year it received $\$ 5.4$ billion in income (5\% of gross domestic product; GDP) from rates, central government, investments and fees and fines, and spent $\$ 5.3$ billion on roads and transport, governance, and culture, recreation and sport (Localcouncils.govt.nz, 2007; The Department of Internal Affairs, 2006, 2007). It employed 25250 people, which represents $1.2 \%$ of all people employed in New Zealand (The Department of Internal Affairs, 2006; 2007).

Transparency in policy making and accountability for the use of taxpayers' funds are fundamental principles of democratic government (Pallot, 2001). Accountability is described by Gray, Owen and Adams (1996:38) as "the duty to provide an account (by no means a financial account) or reckoning of actions for which one is held responsible". In order for the 
accountability relationship to exist, one party (the 'accountor') must be accountable to another party (the 'accountee') for an action, process, output or outcome (Steccolini, 2004). Accountability involves being "obliged to explain one's actions, to justify what one does" (Steccolini, 2004:330) and is vitally important in a situation where one party has stewardship or control of another party's assets. Transparency is described by Pallot (2001) as referring to the availability of information to the public on the transactions of the government and the transparency of the decision-making process.

Annual reports are considered to be the primary mechanism for the discharge of accountability and demonstration of transparency to stakeholders (Coy \& Dixon, 2004; Pallot, 2001). Accountability is discharged through reporting of comprehensive information about the condition, performance, activities and progress of the local government in the changing context within which it operates (Coy \& Dixon, 2004). This is considered true not only for commercial entities, but also for local governments that prepare their financial statements according to commercial principles. Increasingly in the corporate sector, entities are recognising the value of intellectual capital reporting for enhancing the transparency and information content of their annual reports.

\subsection{Investment in intellectual capital}

Investment in research and development (R\&D) and education of employees are typically indicative of investment in intellectual capital (Dumay, 2007). Typically, the local government sector does not does not spend on R\&D; however, it is recognised by Del Bello (2006) that public organisations are largely built on intangibles, such as skills, competences, procedures and information systems. Public sector entities also generate intangibles of a collective nature with their actions, such as public welfare, quality of life, protection of the environment, and reputation of a territory (Del Bello, 2006). Additionally, a significant portion of the New Zealand local government sector expenditure relates to its employees. Employee costs amounted to $\$ 1.2$ billion for the year ended 30 June 2006, or approx $22 \%$ of total expenditure (Localcouncils.govt.nz, 2007; The Department of Internal Affairs, 2007). This represents a significant portion of overall expenditure and could relate to a significant amount of intellectual capital. Public sector entities can therefore be seen as catalysts, generators and managers of intangible resources classified as human, relational and organisational capital (Del Bello, 2006).

\section{PRIOR LITERATURE}

There is a growing body of literature on managing, measuring and reporting intellectual capital. This paper focuses on just one aspect of this literature - reporting intellectual capital in the annual report. A number of intellectual capital disclosure studies have been conducted around the world. Studies of corporate annual report disclosure within countries include Australia (Guthrie \& Petty, 2000; Guthrie, et al., 1999), Canada (Bontis, 2003), Ireland (Brennan, 2001), Italy (Bozzolan, Favotto \& Ricceri, 2003), Malaysia (Goh \& Lim, 2004; Ordóñez de Pablos, 2002), New Zealand (Miller \& Whiting, 2005; Wong \& Gardner, 2005), Singapore (Firer \& Williams, 2005), Spain (Ordóñez de Pablos, 2003), Sri Lanka (Abeysekera \& Guthrie, 2005), Sweden (Olsson, 2001) and the UK (Shareef \& Davey, 2005; Williams, 2001). Comparisons of intellectual capital reporting practices between countries include Asia, Europe and the Middle East (Ordóñez de Pablos, 2002) the Netherlands, Sweden and the UK (Vandemaele, Vergauwen \& Smits, 2005) and 
Sri Lanka and Australia (Abeysekera, 2007). These studies have investigated intellectual capital reporting through content analysis of the annual reports of corporate entities.

Following an extensive literature search, two case studies were identified which focused on intellectual capital reporting by government organisations. A case study by Dumay (2007) investigated the narrative disclosure of intellectual capital in the annual reports of the New South Wales Department of Lands, an Australian government department. Collier (2001) presented a case study of intellectual capital in a different context, instead focusing on how intellectual capital was acquired, utilised and reported by the UK police force.

\section{RESEARCH PUESTION AND METHODOLOGY}

\subsection{Research question}

This paper examines the extent to which the New Zealand local government sector voluntarily discloses the components of intellectual capital in the annual report, and the form that this reporting takes.

\subsection{Population and sample}

There are 85 local authorities that comprise the New Zealand local government sector. Annual reports were obtained from 82 local authorities, and these were used in the content analysis. The three local authorities that were omitted from the study due to difficulties in obtaining their annual report were Invercargill City Council, West Coast Regional Council, and Marlborough District Council. The final list comprised 68 territorial authorities, 11 regional authorities and 3 unitary authorities (see APPENDIX A).

\subsection{Content analysis of annual reports}

A content analysis of the annual reports of the 82 local government authorities was carried out using a weighted disclosure index. The disclosure index was constructed according to the stakeholder principles espoused by Coy and Dixon (2004). The intellectual capital items for the disclosure index were based on previous intellectual capital content analysis studies but modified in order to apply to the local government sector. The intellectual capital disclosure index is discussed in more detail in Schneider and Samkin (2008).

The disclosure index comprised 26 items across three intellectual capital categories. These are presented in TABLE 2. The disclosure index was applied to 82 local authority annual reports. As the study focused on voluntary reporting, information required by legislation or accounting standards was not taken into account. 
TABLE 2a: Intellectual capital disclosure index

\begin{tabular}{|c|c|}
\hline Internal Capital & \\
\hline Intellectual property & Detail of patents, copyrights, trademarks held by local authority \\
\hline Management philosophy & As evidenced by vision/mission statements \\
\hline Management processes & Relating to processes within local authority \\
\hline Corporate culture/values & $\begin{array}{l}\text { Comprises the attitudes, experiences, beliefs and values of the } \\
\text { local authority }\end{array}$ \\
\hline Information/networking systems & $\begin{array}{l}\text { Details on the development, use, application and influence of } \\
\text { information systems }\end{array}$ \\
\hline Financial relations & Relationships between the local authority and finance providers \\
\hline Promotional tools & $\begin{array}{l}\text { Advertising the local authority does to promote its services or its } \\
\text { region }\end{array}$ \\
\hline
\end{tabular}

Source: Author

TABLE 2b: Intellectual capital disclosure index

\begin{tabular}{ll}
\hline \multicolumn{2}{c}{ External Capital } \\
\hline Brands & Details of brands associated with the local authority \\
Ratepayer database & Database of all ratepayers \\
Ratepayer demographics & Information relating to ratepayers \\
Ratepayer satisfaction & Indicators of ratepayer satisfaction \\
Backlog work & Relating to unfinished/un-started projects \\
Distribution channels & Information on how local authority services/products reach users \\
Joint ventures/ collaborations & Involving the local authority \\
Licensing agreements & Held by the local authority \\
Quality standards & Adherence to quality assurance programs/standards \\
\hline
\end{tabular}

Source: Author

TABLE 2c: Intellectual capital disclosure index

\begin{tabular}{ll}
\hline \multicolumn{2}{c}{ Human Capital } \\
\hline Know-how & Employee knowledge \\
Education programs & Education/ongoing programmes initiated by local authority \\
Vocational qualifications & Non academic qualifications held by employees \\
Work-related knowledge & Gained 'on the job' or as part of ongoing training \\
Cultural diversity & Demographic information of employees \\
Entrepreneurial innovativeness & Focusing on cost-minimisation rather than profit-maximisation \\
Equal Employment Opportunities & Details of EEO programs/initiatives \\
Executive compensation plans & Details of executive remuneration \\
Training programs & Undertaken/provided by the local authority \\
Union activity & Details of unions representing employees \\
\hline
\end{tabular}

Source: Author 


\section{RESULTS}

\subsection{Intellectual capital disclosures in NZ local authority annual reports}

The disclosure of intellectual capital in the annual reports is examined from two perspectives. Firstly, the frequency of disclosure of particular intellectual capital items is assessed. Thereafter, examples of disclosures are reproduced from annual reports.

\subsection{Disclosure frequencies}

The intellectual capital items identified in the disclosure index (TABLE 2) were examined in the annual reports of the New Zealand local government sector. TABLE 3 presents the disclosure frequencies of items from the content analysis of the annual reports of 82 local authorities.

TABLE 3a: Frequency of reporting specific intellectual capital attributes

\begin{tabular}{lcc}
\hline \multicolumn{1}{c}{ Internal Capital } & No. & $\%$ \\
\hline Intellectual property & 0 & 0 \\
Management philosophy & 66 & 80 \\
Management processes & 79 & 96 \\
Corporate culture/ values & 75 & 91 \\
Information/networking systems & 58 & 71 \\
Financial relations & 64 & 78 \\
Promotional tools & 72 & 88 \\
\hline
\end{tabular}

Source: Author

TABLE 3b: Frequency of reporting specific intellectual capital attributes

\begin{tabular}{lcc}
\hline \multicolumn{1}{c}{ External Capital } & No. & $\%$ \\
\hline Brands & 14 & 17 \\
Ratepayer database & 7 & 9 \\
Ratepayer demographics & 44 & 54 \\
Ratepayer satisfaction & 66 & 80 \\
Backlog work & 58 & 71 \\
Distribution channels & 78 & 95 \\
Joint ventures/collaborations & 79 & 96 \\
Licensing agreements & 2 & 2 \\
Quality standards & 77 & 94 \\
\hline
\end{tabular}

Source: Author 
TABLE 3c: Frequency of reporting specific intellectual capital attributes

\begin{tabular}{lcc}
\hline \multicolumn{1}{c}{ Human Capital } & No. & $\%$ \\
\hline Know-how & 39 & 48 \\
Education programs & 68 & 83 \\
Vocational qualifications & 22 & 27 \\
Work-related knowledge & 28 & 34 \\
Cultural diversity & 23 & 28 \\
Entrepreneurial innovativeness & 7 & 9 \\
Equal Employment Opportunities & 36 & 44 \\
Executive compensation plans & 17 & 21 \\
Training programs & 53 & 65 \\
Union activity & 8 & 10 \\
\hline
\end{tabular}

Source: Author

The results of the content analysis show that, on the whole, local authorities do voluntarily disclose intellectual capital information in the annual report. The intellectual capital items management processes and joint ventures/business collaborations were disclosed by 79 local authorities (96\%), while only 2 local authorities (2\%) disclosed any information about licensing agreements. No local authorities disclosed any information regarding intellectual property. Overall, information in the internal capital category was disclosed most frequently, with 59 local authorities (72\%) disclosing some information in this category. Human capital was the least disclosed category: on average only 30 local authorities (37\%) disclosed any information in this category.

While the itemised results of this study are not directly comparable to other intellectual capital disclosure studies that focus solely on corporate entities and use different coding frameworks, some general comparisons can be made. TABLE 4 shows comparisons of intellectual capital categories with Guthrie and Petty's (2000) study of the top 20 Australian listed firms, Brennan's (2001) study of 11 knowledge-based Irish firms, and Wong and Gardner's (2005) study of $60 \mathrm{New}$ Zealand listed companies. These studies used the same framework based on the intellectual capital approach. This study was also based on the intellectual capital approach; however, individual items were modified for relevance to local authorities.

TABLE 4: Average disclosure frequency by category

\begin{tabular}{lcccccccc}
\hline & \multicolumn{2}{c}{ This study } & \multicolumn{2}{c}{$\begin{array}{c}\text { Guthrie \& Petty } \\
\text { (2000) }\end{array}$} & \multicolumn{2}{c}{ Brennan (2001) } & \multicolumn{2}{c}{$\begin{array}{c}\text { Wong \& Gardner } \\
\text { (2005) }\end{array}$} \\
& No. & $\%$ & No. & $\%$ & No & $\%$ & No. & $\%$ \\
& 82 & $100 \%$ & 20 & $100 \%$ & 20 & $100 \%$ & 60 & $100 \%$ \\
\hline Internal capital & 59 & 72 & 6 & 29 & 1 & 12 & 18 & 30 \\
External capital & 47 & 58 & 7 & 39 & 2 & 20 & 20 & 33 \\
Human capital & 30 & 37 & 8 & 42 & 2 & 14 & 16 & 26 \\
\hline
\end{tabular}

Source: Author 
Guthrie and Petty (2000) used content analysis to enquire into the intellectual capital reporting practices of the top 20 Australian listed companies as at December 1998. The coding framework consisted of 24 variables divided into three intellectual capital categories derived from Sveiby's (1997) intellectual capital framework: internal structures, external structures, and employee competence. The items were scored according to a four-point scale $(0-3)$. Results from these studies indicate a lack of understanding by the companies studied of the key components of intellectual capital combined with inadequate definitions and inefficient management of intellectual capital. The studies showed that the main areas of intellectual capital reporting by the sample of Australian companies focused on human resources, technology and intellectual property rights, and organisational and workplace structure.

Brennan (2001) replicated the content analysis methodology adopted by Guthrie \& Petty (2000) to examine the extent to which 11 knowledge-based lrish listed companies adopted intellectual capital disclosure methodologies in their annual reports. Brennan (2001) used a content analysis instrument consisting of 24 intellectual capital disclosure variables arranged across three categories: internal structure, external structure, and employee competence. Items were coded using a dichotomous scale: zero for non-disclosure of the item or one for disclosure of the item. The study found that despite the companies having a substantial level of non-physical, intangible, intellectual capital assets, the level of disclosure of intellectual capital attributes by the 11 listed companies was low.

Wong and Gardner (2005) conducted a content analysis on the annual reports of $60 \mathrm{New}$ Zealand companies listed on the New Zealand Stock Exchange. The content analysis coding instrument consisted of 18 intellectual capital indicators organised into three categories based on Sveiby's (1997) framework: internal capital, external capital and human capital. The intellectual capital items were scored using a three-point scale from zero (no disclosure) to three (quantitative disclosure). The results of the study showed that the majority of intellectual capital disclosures were in the external capital category, followed by human capital, with internal capital items being least disclosed.

From the summary statistics provided in TABLE 4, it would appear that on the whole there was a higher frequency of intellectual capital disclosure in the New Zealand local government sector annual reports, than in commercial sector annual reports (see Brennan, 2001; Guthrie \& Petty, 2000; Wong \& Gardner, 2005). While there is no empirical evidence to explain the higher level of disclosure, it could be due to the nature of the local government sector, which is characterised by a high level of public consultation and engagement. Additionally, the provision of voluntary intellectual capital information by local authorities is unlikely to lead to a loss of competitive advantage. This can be contrasted with the often-cited reason by commercial entities for not providing voluntary information in the annual report.

\subsection{Examples from annual reports}

Examples from annual reports are reproduced below to illustrate the nature of intellectual capital disclosures in the annual reports. The examples were chosen to illustrate disclosures on each intellectual capital item in TABLE 2, and to show the breadth and depth of the disclosures.

\subsubsection{Internal capital}

This was the most frequently reported category of intellectual capital, with disclosures being made by $72 \%$ of the local authorities regarding one or more intellectual capital attributes. 
Auckland City Council explicitly stated their mission statement (management philosophy) as follows:

Our mission - To provide excellent leadership and sustainable community services to improve the quality of life for the people in the city of Auckland. (Auckland City Council, 2005 annual report, 2).

New Plymouth District council provided considerable detail on management processes explaining their civic and democracy services:

Its effective operation ensures that councillors, community boards, committees and working parties are able to make a positive contribution towards the community outcomes, through the provision of support, advice and procedural guidance. The service ensures that decisions concerning the outcomes are achieved in a way that is open, honest and transparent. Essentially this support function provides the cornerstone for effective decision making throughout the council (New Plymouth District Council, 2005 annual report, 74).

Environment Waikato also presented detailed information on their civic election process (management processes):

The Region's people are represented by 14 Councillors, who are elected every three years. Elections were held in October 2004. Councillors meet regularly to discuss and make decisions on a wide variety of resource management issues (Environment Waikato, 2005 annual report, 6).

Opotiki District Council was one of 79 local authorities (91\%) that provided disclosures on culture/values. The following represents an extract of their value statement:

Integrity and Honesty - we will not compromise our values and will act in a trustworthy manner at all times. Leadership - we will take an active role in issues that affect our community by providing governance, representation, advocacy, guidance and opinion. Openness and Accountability - we will conduct our affairs in a way that allows the community to see and understand our actions and achievements and we will accept responsibility for them (Opotiki District Council, 2005 annual report, 2).

Porirua City Council provided excellent detail on its database system recently implemented in the city library (information/networking systems):

Porirua City Library launched a Knowledge Centre, which offers public access to some top-notch databases. The library has banded together with other libraries from around NZ to buy a new selection of electronic resources, called EPIC. EPIC can be accessed from the Knowledge Centre which has three dedicated computers which can be used to tap into several authoritative databases. Improving access to information and knowledge helps to contribute to the cultural, social, environmental, and economic well-being of the City. The EPIC databases include over 100,000 recommended titles, more than 60,000 plot summaries and award information from 562 awards, all to help users uncover new reading adventures, find long-remembered favourites and discover award-winning titles (Porirua City Council, 2005 annual report, 9).

Horowhenua District Council provided detail on donations received from an outside party (financial relations): 
When the Council was about to demolish the old building on the Durham Street property purchased in the previous year, some community groups suggested that it could instead be developed as a youth centre, with refurbishing work financed by the $\$ 82845$ donation from Contact that is held by the Council (Horowhenua District Council, 2005 annual report, 12)

This is contrasted with disclosures made by Opotiki District Council with limited reference to financial relations in the following statement:

Grants [were] made to Fibre and Fleece and Tourism Eastland and [a] contribution [was] made to the Regional Economic Development Agency for the Eastern Bay of Plenty (REDA) (Opotiki District Council, 2005 annual report, 54).

Upper Hutt City Council made the following disclosure on events staged by the city to attract visitors (promotional tools):

The Visitor Information Centre continues to play an active role in a large number of major community events for the promotion of Upper Hutt and the benefit of its residents. Some of these highlights were the International Jousting Competition at Harcourt Park (which attracted a record 15000 crowd), the Rimutaka Spring Festival, Moto-X at the Trentham Racecourse, Fireworks Fantastic at Trentham Memorial Park and the Summer Carnival (Upper Hutt City Council, 2005 annual report, 5).

\subsubsection{External Capital}

This was the second most frequently reported category of intellectual capital with disclosures being made by $58 \%$ of the local authorities regarding one or more external capital attributes.

Disclosures of 'brands' were limited to information of logos/crests of the local authorities. The disclosures provided by Rangitikei District Council and Manawatu District Council are indicative of information provided on Council logos.

The logo symbolises the strength of the river, a unique icon, which bisects the District. The sun's rays represent the healthy environment and the genuine natural elements of the Rangitikei culture and lifestyle. The typography and use of colour is typical of a romanticised era in New Zealand's past and is seen in the signage and packaging from the 1920s to the 1950s when the District experienced considerable growth (Rangitikei District Council, 2005 annual report, 12).

The logo for the Manawatu District Council has a flowing style of "M" endeavoring [sic] to give the feeling of the hills that are prominent around this area. The tail of the " $M$ " becomes smoother to indicate the relatively flat plains within the hills. The Manawatu River through the hills is also indicated by the flowing " $M$ ". The "M moves over 5 diagonal bars representing the 5 former Councils which make up the new district (Feilding Borough Council, Kiwitea County Council, Manawatu District Council, Oroua County Council and Pohangina County Council). The feeling of movement also indicates that the council will be seen as a lively, progressive and forward thinking local authority (Manawatu District Council, 2005 annual report, 109).

Only $9 \%$ of local authorities provided any information about the existence of a ratepayer database. Buller District Council and Auckland City Council illustrate the brief nature of the disclosures: 
Council staff has established a stakeholder database, and are working to further develop a resource of local community groups and organisations working with Maori within the district (Buller District Council, 2005 annual report, 37).

Auckland City now has a database of about 300 groups it can notify directly about upcoming New Zealand Maori social gathering or assembly (hui) (Auckland City Council, 2005 annual report, 36).

Auckland City Council provided excellent information about the demographics of their population (ratepayer demographics), as illustrated by the following extract:

- The population was estimated to be 422701 at June 2004.

- The population is projected to reach 530600 by 2021.

- 98 per cent of residents live on the isthmus, which excludes the Hauraki Gulf islands - the population density for this area is about 23 people per hectare.

- The Hauraki Gulf islands have a population density of about 0.2 people per hectare. However, most of the residents (86\%) live on Waiheke Island.

- The median age of residents is 33.3 years.

- 10 per cent of the population is aged 65 years and over.

- 39 per cent of residents were not born in New Zealand (Auckland City Council, 2005 annual report, 176).

Indicators of ratepayer satisfaction were disclosed by $80 \%$ of local authorities. New Plymouth District Council's Chief Executive explained the reason for their ratepayer satisfaction measures:

It is important that the council understands whether the community is satisfied, or not, with the services the council provides. For this reason we carry out an independent survey of New Plymouth residents and ask them how satisfied they are with council services... only two of the council's services received a satisfaction rating below 80 per cent. These two services, parking and public toilets are traditionally difficult services for most councils (New Plymouth District Council, 2005 annual report, 3).

While North Shore City Council provided detailed information on how their ratepayer satisfaction survey was carried out:

TNS New Zealand Ltd was commissioned in 2005 to undertake North Shore City Council's annual survey of residents and businesses. The survey primarily measures respondent use of, and satisfaction with, a range of council services. The survey was conducted using telephone interviews, consistent with previous years. A total of 1,250 North Shore City residents aged 18 and over participated in the external survey. The margin of error at 95 per cent confidence level is \pm 2.8 per cent. The number of business respondents to the survey was 500. The margin of error at 95 per cent confidence level is \pm 4.4 per cent.

The survey scales used were as follows: 1 (Very satisfied); 2 (Satisfied); 3 (Neutral) 4 (Not satisfied); 5 (Not at all satisfied).A positive rating is either 1 or 2 (North Shore City Council, 2005 annual report, 40).

Backlog work represents planned projects that have not commenced or been completed during the financial year. $71 \%$ of local authorities disclosed information on backlog work. Manukau City 
Council provided the following disclosure:
Major Passenger Transport Projects - under spent - $\$ 464000$ - The under spent portion of the budget has been carried forward to the 2005/06 year. Two projects were not completed during the year due to ongoing negotiations over the replacement of a verandah [sic] with adjoining land owners plus redesign of the project to keep costs within budget (Manukau City Council, 2005 annual report, 75).

North Shore City Council provided detailed information regarding wastewater services provided to ratepayers (distribution channels):

\begin{abstract}
Wastewater is collected from over 200000 people through private drains leading from bathrooms, kitchens, laundries and toilets, and also tradewaste from commercial premises. This is then piped and pumped through our public drain network to our Rosedale Wastewater Treatment Plant. After treatment the solid wastes are discharged to landfill and the treated effluent (liquid) is discharged through our outfall, 600 metres out to sea off Kennedy Park. A few residents have septic tanks which are not connected to our network. The wastewater system carries and treats approximately 46 million litres of liquid waste per day from households, businesses and industries. The system includes more than $1280 \mathrm{~km}$ of pipes, 27700 manholes, 91 pumping stations, a treatment plant and ocean outfall. The total replacement cost of the system would be around \$556 million (including \$79 million for the treatment plant). The current condition of the wastewater system varies from excellent in the new high-quality treatment facilities through to average and poor in some of the oldest parts of the city. An analysis of the wastewater reticulation network indicated that 70 per cent of pipes are likely to be in good or excellent condition (North Shore City Council, 2005 annual report, 47).
\end{abstract}

The following disclosure by Queenstown Lakes District Council represents joint ventures/business collaborations:

This activity requires the council to work in close partnership with Transfund New Zealand who fund a portion of local roads through national levies and Transit New Zealand who provide the complementary state highway network (Queenstown Lakes District Council, 2005 annual report, 69).

Similarly, Southland District Council provided detailed disclosure regarding a joint project between four councils:

The four councils within Southland (Southland District Council, Environment Southland, Invercargill City Council and Gore District Council) undertook a joint project "Our Way - Southland" to identify outcomes the community (Southland District Council, 2005 annual report, 7).

Licensing agreements was only disclosed by $2 \%$ of local authorities. Napier City Council provides an example:

Five organisations have service agreements/purchase contracts with the Napier City Council; Creative Napier, Hawke's Bay Life Saving, Napier Citizens Advice Bureau, Neighbourhood Support and Sport Hawke's Bay and all met the reporting requirements. (Napier City Council, 2005 annual report, 54)

The majority of 'quality standards' disclosures related to the achievement of drinking water quality standards. Auckland City Council made the following disclosures regarding their 
drinking water:

Auckland city's drinking water continues to be of a high standard. In 2004/2005 it again received an Aa grading from the Ministry of Health for both treatment at source and distribution (Auckland City Council, 2005 annual report, 33).

Some discourses relating to 'quality standards' highlighted achievement of ISO standards. The following is an example from Waitaki District Council's annual report:

Target: $\quad$ To ensure the Company* maintains required quality standards.

Measure: $\quad$ To maintain ISO 9001 registration and related quality assurance progresses.

Achievement: The Company has passed its last audit in March 2005 and is maintaining its registration and quality assurance programmes (Waitaki District Council, 2005 annual report, 67)

* This refers to Whitestone Limited a Council Controlled Trading Organisation set up under the Local Government Act 2002

\subsubsection{Human Capital}

This was the least reported category of intellectual capital, with disclosures being made by only $37 \%$ of the local authorities regarding one or more human capital attributes.

Just under half of all local authorities (48\%) disclosed information on 'know-how'. An example is given by Auckland Regional Council regarding the skills of their staff:

Technical skills are wide-ranging; from water quality scientists, volcanologists and botanists, to expert boat-handlers, park rangers and project managers. Our recruitment policy is to 'hire for fit 'rather than for expertise alone. Employees of the ARC are increasingly mobile, moving between technical, educational, management and strategic planning areas depending upon their skills, experience and areas of interest (Auckland Regional Council, 2005 annual report, 74).

Education programs were the highest reported human capital attribute, with $83 \%$ of local authorities disclosing information on this item. Disclosure levels varied from detailed (Greater Wellington Regional Council) to brief (Waitomo District Council, Horizons Regional Council):

The numbers of students taking action for the environment through our education programmes exceeded 2200 this year and the Be the Difference campaign, which assists households to look after the environment day to day, now has over 12,000 members. (Greater Wellington Regional Council, 2005 annual report, 3)

Staff supported educational programmes with schools involving planting days on western beaches. (Horizons Regional Council, 2005 annual report, 23)

Six educational visits were made to schools and community groups. (Waitomo District Council, 2005 annual report, 55)

Other local authorities such as Auckland Regional Council detailed education programs provided to their staff:

The ARC offers staff a variety of education and training programmes. A number of courses are run in-house, by external providers, or in partnership with the Auckland University School of Business. These include: leadership development, 
communication skills, project management, conflict resolution, various computer courses, facilitation skills, iwi protocol, presentation skills and report writing. (Auckland Regional Council, 2005 annual report, 75)

Vocational qualifications were disclosed by $27 \%$ of local authorities. Hauraki district council provided the following disclosure of their technically qualified staff:

The Council employs a number of technically qualified staff in such areas as water, wastewater, planning, inspection, roading [sic] and a range of other Council activities (Hauraki District Council, 2005 annual report, 17).

Stratford District Council made the following disclosures regarding the competency of its staff:

All staff are fully trained, or in the process of being trained for all travel and $A A$ services provided at the Centre (Stratford District Council, 2005 annual report, 69).

Details of educational/academic qualifications held by staff were not considered to be part of the item 'vocational qualifications'. However, a number of councils including Auckland City Council and Waitakere City Council provided the qualifications of their executive management teams and/or the elected representatives. Many councils, including North Shore City Council and Thames-Coromandel District Council, provided the names of their staff who were Justices of the Peace.

Gore District council provided very brief narrative on the work-related knowledge of its staff:

... skilled and knowledgeable staff to help people find the information they need

(Gore District Council, 2005 annual report, 20).

Similarly, Whangarei District Council made the following statements about ensuring their staff have the right technical expertise for the job (work-related knowledge):

A challenge for the Whangarei District Council is finding and retaining the right people. To ensure we have a global pool of talent to choose from, particularly for roles requiring technical expertise (civil engineers, planners and environmental health officers), the Whangarei District Council advertises through national print media and internationally via its' website (Whangarei District Council, 2005 annual report, 16).

Cultural diversity was disclosed by $28 \%$ of local authorities. Manukau City Council commented on the cultural diversity of its workforce while talking about its New Zealand Accident Compensation Corporation Workplace Safety Management Practices Scheme (ACC) Tertiary Accreditation status:

... this allows Council to provide a safe and healthy working environment for its culturally diverse workforce and equally (given the diverse nature of its responsibilities and accountabilities) over a large multicultural metropolitan population (Manukau City Council, 2005 annual report, 39).

Entrepreneurial innovativeness refers to cost-minimisation relating to council activities. Only $9 \%$ of local authorities disclosed information regarding this item. Thames-Coromandel District Council made the following statement about cost-minimisation:

Council will continue to provide cost effective governance and services (ThamesCoromandel District Council, 2005 annual report, 36).

While Waitomo District Council analyse variances to control costs: 
Monitoring of actual activity volume to expected volume is a key operational management device for controlling costs (Waitomo District Council, 2005 annual report, 50).

Equal Employment Opportunities (દદ0) was disclosed by $44 \%$ of local authorities. Manawatu District Council and Waitomo District Council provided detailed information on their દદ0 policies:

The Manawatu District Council is committed to developing equal opportunities for current and future employees. The Council believes fair employment practices are essential for an efficient and effective workforce to be maintained. Staff will be recruited, appointed, trained and promoted on the basis of their paid and unpaid work experience, ability, skills and future potential (Manawatu District Council, 2005 annual report, 118).

Waitomo District Council also provided excellent information regarding their $\varepsilon \varepsilon 0$ policy. An extract of their policy is shown below:

Waitomo District Council prides itself on being an Equal Opportunity Employer. We have set ourselves several objectives and targets as performance measurement criteria. The Council believes that it has to provide leadership and also be a model to the District in this regard (Waitomo District Council, 2005 annual report, 14).

The policy also included a table showing the percentage achievement of various targets (TABLE 5).

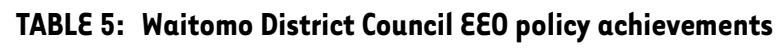

\begin{tabular}{lcc}
\multicolumn{1}{c}{ Objectives } & Targets & Result \\
\hline $\begin{array}{l}\text { To foster a positive climate in the workplace aimed at } \\
\text { encouraging employees to develop their potential and to } \\
\text { remove discriminatory barriers to employment. }\end{array}$ & $\begin{array}{c}\text { No complaints } \\
\text { upheld }\end{array}$ & $100 \%$ successful \\
Ell employment policies and practices will have regard to \\
the Treaty of Waitangi and will comply with the provisions \\
of the Human Rights Act 1993, the Equal Pay Act 1972 \\
$\begin{array}{l}\text { and the Employment Relations Act } 2000 \text { and other } \\
\text { relevant statutes. }\end{array}$ \\
$\begin{array}{l}\text { Employment decisions will continue to be made solely } \\
\text { upon merit, qualifications and work history relating to } \\
\text { the position to be filled. }\end{array}$ \\
$\begin{array}{l}\text { Opportunities for training, transfer and promotion will be } \\
\text { made available to al employees. }\end{array}$ \\
$\begin{array}{l}\text { To promote a workplace free of discrimination and } \\
\text { harassment. }\end{array}$
\end{tabular}

Source: Waitomo District Council (2005 annual report, 14).

Executive compensation plans refers to disclosure of employee remuneration or benefit plans paid to employees. Disclosure of 'executive compensation' is a legislated requirement and a financial reporting requirement. The disclosure instrument only considered disclosures outside of the financial statements as it was focused on assessing voluntary disclosures. Only $21 \%$ of local authorities provided this information outside of the financial statements. 
The majority of the disclosures by local authorities regarding 'training programs' related to Civil Defence training provided to staff. Kaikoura District Council provides a good example:

Training of staff is undertaken annually, plus the entire district works together in at least one major exercise per year, in conjunction with local, regional and national Civil Defence Emergency Management organisations (Kaikoura District Council, 2005 annual report, 93).

Other disclosures of 'training programs' included further educational training to up-skill staff. Environment Canterbury provided the following disclosure of its training and development policy:

Training and development: training and development opportunities are identified individually with each staff member as part of their performance appraisal. An allocation of 30 hours training and development is made per employee (Environment Canterbury, 2005 annual report, 11).

Details of union activity were only provided by $10 \%$ of local authorities. Taranaki Regional Council provide a good example:

Ninety-six permanent staff were employed by the Council at 30 June 2005. Ninetyone percent were employed under the Taranaki Regional Council Collective Employment Agreement, with the balance employed on individual agreements. Staff employed under the collective agreement are represented by the Taranaki Regional Council Officers Staff Association Incorporated. There were no disputes or personal grievances which triggered the "employment relationship problems" provisions of the Taranaki Regional Council Collective Employment Agreement during the period (Taranaki Regional Council, 2005 annual report, 71).

\section{CONCLUSIONS}

This preliminary research into intellectual capital reporting by local authorities indicates that overall intellectual capital disclosure in the annual report is varied. Disclosures for specific intellectual capital attributes ranged from none (0\%) to 79 local authorities (96\%) making disclosures. Despite the New Zealand local government sector employee/staff expenses comprising a considerable portion of total expenditure, human capital reporting in the annual reports is low.

The results indicate that, on average, only $37 \%$ of human capital indicators are reported in annual reports. Most of the intellectual capital disclosures are in narrative form, with limited disclosures including financial or numeric information. The reporting of intellectual capital items does not appear to be made within a consistent framework, as the provision of such information is voluntary. The findings of this research are consistent with prior intellectual capital annual report disclosure studies, which found low levels of intellectual capital reporting.

\section{LIMITATIONS OF THE RESEARCH}

The findings of the study are based on the annual reports of the New Zealand local government sector. The findings may not be comparable with local governments in other jurisdictions due to differences in the regulatory and financial reporting frameworks. Nevertheless, the study 
provides a valuable insight into intellectual capital reporting practices of the New Zealand local government sector.

\section{REFERENCES}

Abeysekera, I. (2007). Intellectual capital reporting between a developing and developed nation, Journal of Intellectual Capital, 8(2), pp. 329-345.

Abeysekera, I. \& Guthrie, J. (2005). An empirical investigation of annual reporting trends of intellectual capital in Sri Lanka, Critical Perspectives on Accounting, 16(3), pp. 151-163.

Bontis, N. (2003). Intellectual capital disclosure in Canadian corporations, Journal of Human Resource Costing and Accounting, 7(1/2), pp. 9-20.

Bontis, N., Dragonetti, N. C., Jacobsen, K. \& Roos, G. (1999). The knowledge toolbox: a review of the tools available to measure and manage intangible resources, European Management Journal, 17(4), pp. 391-402.

Bornermann, M., Knapp, A., Schneider, U. \& Sixl, K. I. (1999). Holistic measurement of intellectual capital. International Symposium. Measuring and reporting intellectual capital: experiences, issues and prospects, Amsterdam, 9-11 June 1999.

Bozzolan, S., Favotto, F. \& Ricceri, F. (2003). Italian annual intellectual capital disclosure, Journal of Intellectual Capital, 4(4), pp. 543-558.

Brennan, N. (2001). Reporting intellectual capital in annual reports: evidence from Ireland, Accounting, Auditing \& Accountability Journal, 14(4), pp. 423-436.

Brooking, A. (1996). Intellectual Capital: Core Assets for the Third Millennium. London: Thomson Business Press.

Canadian Performance Reporting Initiative. (1998). Total Value Creation. Available from: http://cpri.matrixlinks.ca/tvc/index.html. (Accessed 22 July 2007)

Collier, P. M. (2001). Valuing intellectual capacity in the police, Accounting, Auditing \& Accountability Journal, 14(4), pp. 437-455.

Coy, D. \& Dixon, K. (2004). The public accountability index: crafting a parametric disclosure index for annual reports, The British Accounting Review, 36(1), pp. 79-106.

Del Bello, A. (2006). Intangibles and sustainability in local government reports, Journal of Intellectual Capital, 7(4), pp. 440-456.

Dumay, J. C. (2007). Narrative Disclosure of Intellectual Capital: A Structurational Analysis. Fifth Asia Pacific Interdisciplinary Research in Accounting Conference, 8-10 July 2007, Auckland, New Zealand.

Edvinsson, L. \& Malone, M. S. (1997). Intellectual Capital: Realizing Your Company's True Value by Finding Its Hidden Brainpower. New York: HarperBusiness.

Fincham, R. \& Roslender, R. (2003). The Management of Intellectual Capital and Its Implications for Business Reporting, Institute of Chartered Accountants of Scotland.

Firer, S. \& Williams, S. M. (2005). Firm ownership structure and intellectual capital disclosures, South African Journal of Accounting Research, 19(1), pp. 1-18. 
Goh, P. C. \& Lim, K. P. (2004). Disclosing intellectual capital in company annual reports: Evidence from Malaysia, Journal of Intellectual Capital, 5(3), pp. 500-510.

Gray, R., Owen, D. \& Adams, C. (1996). Accounting \& Accountability: Changes and Challenges in Corporate Social and Environmental Reporting. London: Prentice Hall.

Guthrie, J. \& Petty, R. (2000). Intellectual capital: Australian annual reporting practices, Journal of Intellectual Capital, 1(3), pp. 241-251.

Guthrie, J., Petty, R., Ferrier, F. \& Wells, R. (1999). There is no accounting for intellectual capital in Australia; review of annual reporting practices and the internal measurement of intangibles within Australian organisations. OECD Symposium on Measuring and Reporting of Intellectual Capital, 9-11 June 1999, Amsterdam, pp. 9-11.

Guthrie, J., Petty, R. \& Johanson, U. (2001). Sunrise in the Knowledge Economy: Managing, Measuring and Reporting Intellectual Capital, Accounting, Auditing \& Accountability Journal, 14(4), pp. 365-384.

Kalafut, P. C. \& Low, J. (2001). The Value Creation Index: Quantifying Intangible Value, Strategy and Leadership, 29(5), pp. 9-15.

Kaplan, R. S. \& Norton, D. P. (1992). The balanced scorecard - measures that drive performance, Harvard Business Review, 70(1), pp. 71-79.

Lev, B. (2001). Intangibles: Management, Measurement, and Reporting. Washington: Brookings Institution Press.

Localcouncils.govt.nz. (2007). Your Loca/ Council: shaping communities together. Available from: http://www.localcouncil.govt.nz/lgip.nsf/Files/PDF/\$file/InfoSheet01.pdf. (Accessed 22 July 2007)

Low, J. (2000). The value creation index, Journal of Intellectual Capital, l(3), pp. 252-262.

Lynn, B. (1998). Intellectual capital, CMA Management, 72(1), pp. 10-15.

Miller, J. C. \& Whiting, R. H. (2005). Voluntary disclosure of intellectual capital and the "hidden value". Accounting \& Finance Association of Australia and New Zealand Conference. 4-5 July 2005, Melbourne, Australia.

Mouritsen, J., Bukh, P. N. \& Bang, H. K. (2005). Understanding intellectual capital in an innovative medium-sized firm: The case of Maxon Telecom, Australian Accounting Review, 15(2), pp. 31-39.

Olsson, B. (2001). Annual reporting practices: information about human resources in corporate annual reports in major Swedish companies, Journal of Human Resource Costing and Accounting, 6(1), pp. 39-52.

Ordóñez de Pablos, P. (2002). Evidence of intellectual capital measurement from Asia, Europe and the Middle East, Journal of Intellectual Capital, 3(3), pp. 287-302.

Ordóñez de Pablos, P. (2003). Intellectual capital reporting in Spain: a comparative view, Journal of Intellectual Capital, 4(1), pp. 61-81.

Organisation for Economic Cooperation and Development (OECD). (1999). OECD Symposium on measuring and reporting of intellectual capital. 9-11 June 1999, Amsterdam.

Pallot, J. (2001). Transparency in local government: antipodean initiatives, European Accounting Review, 10(3), pp. 645-660. 
Petty, R. \& Guthrie, J. (2000). Intellectual capital literature review, Journal of Intellectual Capital, l(2), pp. 155-176.

Rodgers, W. (2003). Measurement and reporting of knowledge-based assets, Journal of Intellectual Capital, 4(2), pp. 181-190.

Roos, J., Roos, G., Dragonetti, N. C. \& Edvinsson, L. (1997). Intellectual Capital: Navigating in the New Business Landscape. London: Macmillan.

Schneider, A. \& Samkin, G. (2008). Intellectual capital reporting by the New Zealand local government sector, Journal of Intellectual Capital, 9(3), pp. 207-238.

Shareef, F. \& Davey, H. (2005). Accounting for intellectual capital: Evidence from listed English football clubs, The Journal of Applied Accounting Research, 7(3), pp. 78-116.

Steccolini, I. (2004). Is the Annual Report an Accountability Medium? An Empirical Investigation into Italian Local Governments, Financial Accountability and Management, 20(3), pp. 327-350.

Stewart, T. A. (1997). Intellectual capital: the new wealth of organizations. New York: Doubleday.

Sveiby, K. E. (1997). The New Organizational Wealth: Managing and Measuring Knowledge-Based Assets. San Francisco: Berrett-Koehler Publishers.

The Department of Internal Affairs. (2006). Resource Material: Local Government - what does it do? Available from:

http://www.localcouncil.govt.nz/LGIP.nsf/files/PDF/\$file/LocalGovtWhatltDoes.pdf. (Accessed 31 July 2007)

The Department of Internal Affairs. (2007). Local Government Statistical Overview. Available from: http://www.localcouncils.govt.nz/lgip.nsf/wpg_url/About-Local-Government-LocalGovernment-Statistical-Overview-Index. (Accessed 22 July 2007)

Vandemaele, S. N., Vergauwen, P. \& Smits, A. J. (2005). Intellectual capital disclosure in the Netherlands, Sweden and the UK, Journal of Intellectual Capital, 6(3), pp. 417-426.

Wallis, J. \& Dollery, B. (2000). Local government reform in New Zealand, Working paper series in Economics. Australia: University of New England.

Williams, S. M. (2001). Is intellectual capital performance and disclosure practices related, Journal of Intellectual Capital, 2(3), pp. 192-203.

Wong, M. \& Gardner, C. (2005). Intellectual capital disclosure: New Zealand evidence. Paper presented at the Accounting \& Finance Association of Australia and New Zealand Conference: Melbourne, Australia, 4-5 July 2005. 


\section{APPENDIX A}

Local authorities' population used in study

\begin{tabular}{|c|c|c|c|}
\hline Territorial Authorities & & Regional Authorities & Unitary Authorities \\
\hline Ashburton District & Palmerston North City & Auckland Region & Gisborne District \\
\hline Auckland City & Papakura District & Environment Bay of Plenty & Nelson City \\
\hline Buller District & Porirua City & Environment Canterbury & Tasman District \\
\hline Carterton District & Queenstown Lakes District & Environment Southland & \\
\hline $\begin{array}{l}\text { Central Hawkes Bay } \\
\text { District }\end{array}$ & Rangitikei District & Environment Waikato & \\
\hline Central Otago District & Rodney District & Greater Wellington & \\
\hline Chatham Islands Council & Rotorua District & Hawkes Bay Region & \\
\hline Christchurch City & Ruapehu District & Horizons Manawatu & \\
\hline Clutha District & Selwyn District & Northland Region & \\
\hline Dunedin City & South Taranaki District & Otago Region & \\
\hline Far North District & South Waikato District & Taranaki Region & \\
\hline Franklin District & Southland District & & \\
\hline Gore District & South Wairarapa District & & \\
\hline Grey District & Stratford District & & \\
\hline Hamilton City & Tararua District & & \\
\hline Hastings District & Taupo District & & \\
\hline Hauraki District & Tauranga City & & \\
\hline Horowhenua District & Thames-Coromandel & & \\
\hline f & District & & \\
\hline Hurunui District & Timaru District & & \\
\hline Hutt City & Upper Hutt City & & \\
\hline Kaikoura District & Waikato District & & \\
\hline Kaipara District & Waimakariri District & & \\
\hline Kapiti Coast District & Waimate District & & \\
\hline Kawerau District & Waipa District & & \\
\hline Mackenzie District & Wairoa District & & \\
\hline Manawatu District & Waitakere City & & \\
\hline Manukau City & Waitaki District & & \\
\hline Masterton District & Waitomo District & & \\
\hline Matamata-Piako District & Wanganui District & & \\
\hline Napier City & Wellington City & & \\
\hline New Plymouth District & Western BOP District & & \\
\hline North Shore City & Westland District & & \\
\hline Opotiki District & Whakatane District & & \\
\hline Otorohanga District & Whangarei District & & \\
\hline
\end{tabular}


Schneider \& Samkin 